\title{
Dezoito anos de Cadernos de Saúde Pública
}

O ano de 2002 marca a trajetória de Cadernos de Saúde Pública (CSP) de uma maneira especial: a revista completa 18 anos de publicação. Fundada em 1985 sob a coordenação de Frederico Simões Barbosa e Luis Fernando Ferreira, que também foram seus primeiros editores, CSP logrou consolidar uma rara trajetória dentre as revistas em saúde publicadas na América Latina. Por que rara? Inicialmente porque, ao contrário de tantas outras, a periodicidade e a regularidade de sua publicação mantiveram-se contínuas, não tendo ocorrido interrupções. Em segundo lugar porque, ao longo desses 18 anos, CSP esteve sempre na busca de introduzir inovações de estilo, formato e conteúdo.

O aperfeiçoamento do projeto editorial de CSP foi conduzido ao longo de alguns eixos principais, destacando-se o processo de seleção dos trabalhos, a qualidade gráfica da publicação e os mecanismos de disseminação. Quanto ao primeiro, que se constitui em uma etapa absolutamente crucial do processo de editoração científica, buscou-se ancorálo rigorosamente no sistema de revisão pelos pares. Ainda no campo editorial, vale mencionar a linha inovadora pela qual primou CSP, criando espaços alternativos para a veiculação da discussão acadêmica (debates, entrevistas, opiniões, resenhas), além da publicação de números temáticos, cujo objetivo é oferecer aos leitores o estado da arte nas diferentes especialidades que compõem o campo da Saúde Coletiva.

Importantes investimentos na melhoria da qualidade gráfica e visual de CSP ocorreram a partir de 1996. As mudanças no formato e layout não se deram apenas por uma questão de estética. Após meses de pesquisa, a adoção de novo formato proporcionou uma organização interna mais eficiente do texto em combinação com tabelas e figuras. Além disso, o atual formato da revista permite a publicação de maior número de artigos por fascículo.

Finalmente, em relação à disseminação, trabalhou-se no sentido de a publicação atingir o público mais amplo possível, incluindo os mais diversos profissionais de saúde, pesquisadores e estudantes. Em um mundo no qual coexistem quase cem mil revistas acadêmicas, ser apenas mais um título dentre tantos não é garantia de que seus artigos terão alguma chance de serem lidos. A indexação internacional de CSP foi um dos principais passos na busca de maior visibilidade, tendo sido crucial sua inclusão no sistema Medline, a base mais consultada mundialmente na área da saúde. Mais recentemente, a disponibilização integral dos fascículos publicados na Internet, por meio do sistema SciELO (Scientific Electronic Library Online), integrado ao sistema de busca bibliográfica do Medline, colocou Cadernos de Saúde Pública num seleto conjunto de revistas científicas publicadas na América Latina, com efetivas possibilidades de maior disseminação para outras regiões do mundo.

Em virtude desse arcabouço de fatores, a evolução de CSP, sobretudo no último qüinqüênio, foi marcada por uma crescente internacionalização. Atualmente, cerca de um quinto dos artigos publicados é oriundo do exterior, principalmente de países americanos ou europeus. O fato de autores estrangeiros estarem optando pelas páginas de CSP para publicarem suas idéias e os resultados de suas pesquisas sinaliza que a revista passou a ser conhecida e a gozar de reputação para além das fronteiras nacionais.

A trajetória de CSP foi marcada pela ênfase na concomitância, nem sempre fácil, entre consolidação e renovação. É dessa interação que resulta a vitalidade de um veículo de disseminação de conhecimento científico. Não podemos perder de perspectiva que essa vitalidade não é fruto apenas do trabalho de editores e consultores; pelo contrário, ela se nutre do amadurecimento, da produtividade e da constante efervescência da comunidade acadêmica imediata na qual a revista está inserida. Os 18 anos de CSP significam muito mais do que uma data arbitrária. A nosso ver, constituem um momento de pausa para ouvir, refletir e propor novos caminhos. Cadernos de Saúde Pública é um projeto coletivo, transcendendo limites institucionais específicos, sendo produto do dinamismo da comunidade científica em Saúde Pública brasileira como um todo.

Carlos E. A. Coimbra Jr.

Editor 


\section{Eighteen years of Cadernos de Saúde Pública}

2002 is a year that marks the trajectory of Cadernos de Saúde Pública (CSP) in a special way, the journal completes 18 years of publication. Started in 1985 with the coordination of Frederico Simões Barbosa and Luis Fernando Ferreira, who were also their first editors, CSP consolidated a rare trajectory among health sciences journals published in Latin America. Why rare? Firstly because, contrary to so many other journals, its regularity and periodicity were maintained constant, without interruptions. In second place, during these 18 years, CSP has always been searching to introduce innovations of style, format, and content.

The search for excellence for Cadernos de Saúde Pública editorial project was conducted along some principal lines. In evidence was the careful selection of contributions to be published, the graphic quality of the publication, along with mechanisms of dissemination. The selection of contributions is an absolute crucial stage in science editorship. We have anchored it rigorously to the peer review system. Still within the editorial field, it is worth mentioning the innovative path created by CSP, opening up alternative spaces for academic discussions (debates, opinions, interviews, reviews), in addition to the publication of thematic issues that have the objective of offering the readers the state of the art in different specialties that compose the field of Public Health.

Important investiments to increase the graphic and visual quality of CSP started in 1996. The changes in format and layout were done not only for an aesthetic purpose. After months of research and tests, the adoption of a new format allowed for a more efficient internal organization of the text in combination with tables and figures. In addition to this, the new format of CSP allowed a larger number of articles to be published per issue.

Finally, in regards to the dissemination and distribution of the journal, we have worked with the goal of having the publication reach a wider range of the public, including the most different health professionals, researchers and students. In a world where almost one hundred thousand academic journals co-exist, to be just one more title among so many offers no guarantee that articles will have any chance to be read. The international indexation of CSP was one of the main steps in the search for more visibility. Its inclusion in Medline was crucial; the world's most consulted bibliographic base in the health sciences. Most recently the integral availability of issues on the Internet through SciELO (Scientic Electonic Library on Line - http://www.scielo.br/csp), placed CSP in a select group of scientific journals published in Latin America, thus enhencing the possibilities of a wider distribution of the journal to other world regions.

Taking into consideration all of these factors, CSP in the last five years has become more international. Today, about a fifth of the articles published come from abroad, mainly from European countries and the Americas. The fact that foreign authors are choosing Cadernos de Saúde Pública to publish their ideas and their research results shows the reputation and the respect the journal has gained beyond its national frontiers.

CSP trajectory was marked by the simultaneous need to consolidate and renew, which has not always been easy. The results of this interaction provide the vitality for a vehicle of dissemination of scientic knowledge. We can not lose the perspective that this vitality comes not only from the result of the work done by editors and consultants, but is also nurtured by the maturity, productivity, and constant excitement of the academic community in which CSP is produced. The 18 years of CSP means much more than an arbitrary date. In our view, it is a moment to pause, to listen, and reflect and propose new ideas. Cadernos de Saúde Pública is a collective project transcending specific institutional limits. It is a product that results from the dynamism of the Brazilian public health scientific community as a whole.

Carlos E. A. Coimbra Jr.

Editor 